\title{
Pedagojik Bakımdan Arapça Okuma Dil Becerisinde Materyal Tasarımı*
}

\begin{abstract}
(iD) Ramazan Kılıç**
Atıf/@: Kılıç, Ramazan, Pedagojik Bakımdan Arapça Okuma Dil Becerisinde Materyal Tasarımı, Artuklu Akademi 2019/6 (1),35-65.

Öz: Materyal tasarımı, yabancı dil öğretiminde başarı durumuna etki eden bir konudur. Ülkemiz dâhilinde dizayn edilen materyal oranı son yıllarda geçmişe nazaran ciddi bir artış göstermiştir. Özellikle okuma dil becerisine hitaben oluşturulan bu materyaller, pedagojik bakımdan farklı sorunsalları içlerinde barındırmaktadırlar. Zira yabancı dil öğretimi gayesiyle tasarlanan eserlerin ortak paydada buluşabildikleri kurallar manzumesi mevcut değildir. Bu sebeple eğitimciler, bireysel birikimlerinden hareketle dil öğretim materyalleri tasarlamaktadırlar. Tasarım, eserlerin yalnızca görsele hitap eden yönü değil, aynı zamanda hedef kitleye ulaştırılmak istenen bilgi içeriğinin en iyi şekilde uyarlanması anlamını da ifade etmektedir. Bu bağlamda araştırmamızın konusu, Arapça okuma dil becerisine yönelik materyal tasarımında dikkat edilmesi gereken temel ilkelerin belirlenmesi olacaktır. Dil öğrenmede yaşanan sorunların belli bir kısmının materyal dizaynından kaynaklandığı, bu durumun nasıl aşılabileceği incelenecektir. Tasarıma ek olarak materyallerin kullanımı ile ilgili gerekli bazı konulara da değinilecektir.
\end{abstract}

Anahtar Kelimeler: Yabancı Dil Eğitimi, Arapça Öğretimi, Okuma Becerisi, Materyal Tasarımı, Metin.

\section{Evaluating Material Design in Arabic Reading Skills from Pedagogical Perspective}

Citation/@: Kılıç, Ramazan, Evaluating Material Design in Arabic Reading Skills from Pedagogical Perspective, Artuklu Akademi 2019/6 (1),35-65.

Abstract: Material design is an issue having an impact on the success in teaching second language. In recent years, the proportion of material designed in Turkey has significantly increased compared to the past. These materials, specifically designed for text comprehension, have different pedagogical problems. One of them is that the materials provided for teaching second language are not

* $\quad$ Bu makale, “Arapça Okuma Dil Becerisinde Materyal Tasarımı ve Kullanımı (Özel Amaçlı Dil Eğitim ve Öğretim Örneği)" başlıklı Yüksek Lisans tezimizin üçüncü bölümünden üretilmiştir.

** Arş. Gör., Hitit Üniversitesi İlahiyat Fakültesi Arap Dili ve Belagatı Ana Bilim Dalı, ramazannkilicc@hotmail.com 
designed according to draft joint regulations. Design aims not only to distribute the visual aspect of the material used for language acquisition, but also to convey to the target the content in the reading material at highest level. In this context, the subject of our research will be the determination of basic principles to be considered in the design of materials for reading Arabic. It will be examined how material design causes problems in language acquisition and how this problem can be solved. In addition to the design, some other points related to the use of the materials will be mentioned.

Keywords: Second Language Education, Arabic Teaching, Reading Skill, Material Design, Text.

[The Extended Abstract is at the end of the article.]

\section{Giriş}

Arapça öğretim faaliyetleri yüzyıllar öncesine dayanan bir maziye sahiptir. Bilgiye ulaşmanın son derece kolay olduğu günümüz bilgi çağında, Arapça ve Arapçanın öğretilmesi noktasında problemlerin -geçmişte olduğu gibi- devam ettiği dile getirilmektedir. Bu sorunların başında da Arapça öğretim materyallerinin tasarımı meselesi gelmektedir. Eğitimin vazgeçilmezi olan materyaller, örgün eğitimin tüm aşamalarında kendilerine biçilen vizyonlarını tamamlamaktadır. Böylece eğitimciler de sorumluluklarını yerine getirmiş sayılır. ${ }^{1}$ Eğitimciler açısından motivasyon kavramı, genellikle öğrencilerin eğitimi zevkle almalarından ziyade sınıf içi etkinlikleri benimseyecekleri yolların tespiti olarak anlaşılmıştır. ${ }^{2}$ Realitede materyal ve eğitimcilerin eğitim faaliyetlerindeki misyonu -genellikle- bu şekildeyken hedef kitle ise ölçme-değerlendirme süreçlerinde başarı sağlamakla yetinmektedir. ${ }^{3}$ Böylesi bir planlamada yaygın eğitim alanına biçilen pay yok denecek kadar azdır. Oysa içerisinde öğrenmenin bulunduğu her faaliyet, yaygın boyutta yürütülecek eylemleri gerektirir. Yabancı dil gibi yaşam boyu devam eden bir öğrenme faaliyeti ise bu zorunluluğu olduğundan çok daha fazla hissettirir.

Dil öğrenmenin yaygın boyutta sürdürüleceği en olası beceri ise okumadır. Arapçanın yazıldığı gibi okunma özelliğine sahip olması okuma becerisi adına büyük bir ayrıcalıktır. Yazma ve konuşma gibi beceriler, top-

Hanada Taha-Thomure, "The Status of Arabic Language Teaching Today", Education, Business and Society: Contemporary Middle Eastern Issues, 1/3 (2008): 186.

2 Zoltan Dörnyei, Motivational Strategies in the Language Classroom: Cambridge Language Teaching Library, (Cambridge: Cambridge University Press, 2001), 51.

3 Tom Hutchinson, Alan Waters, English for Specific Purpoes: A learning-Centred Approach, (Cambridge: Cambridge University Press, 1987), 53; David Carver, "Some Propositions About ESP", The ESP Journal, 2/2 (1983): 132. 
lumsal tabanda daha etkin olmayı gerektirirken, okuma ise bireysel olarak da gerçekleştirilebilir. Oldukça kuşatıcı mahiyetteki okuma becerisine yönelik günümüz Arapça öğretim faaliyetlerinde pek çok materyal mevcuttur. Ancak bu materyallerin tasarlanmaları noktasında faydalanılan ortak paydada bir kurallar manzumesi belirlenebilmiş değildir. Oysa materyal tasarımı, alanında uzman kişilerce ortak çalışma yapmayı gerektirmektedir. ${ }^{4} \mathrm{Bu}$ ihtiyaçtan hareketle (okuma becerisi özelinde) materyal tasarımında dikkat edilmesi gerekli belli bazı temel ilkeler belirlenecektir.

\section{Arapça Öğretiminde Okuma Becerisi ve Materyal}

Metin; "yapısal olarak başından sonuna kapalı, dilsel göstergelerin peş peşe geldiği anlamlı bir oluşumdur" ${ }^{5}$ Kozmik yapıda tümcelerden oluşan metin, kapsam bakımından gazete, dergi, roman ve ders kitapları gibi çeşitli yazı formlarını bünyesinde barındırır. ${ }^{6}$ Sistematik/Örgün olarak yürütülen yabancı dil öğretim faaliyetlerinde ders kitapları temel kaynaklar olarak kabul edilir. Ancak bu materyaller dil yeterliliğini olması gerektiği kadar geliştiremediğinden takviye (yardımcı) materyallere her zaman ihtiyaç duyulur. ${ }^{7}$

Yabancı dil öğretiminde materyallerin eğitimci/hedef kitleden kaynaklanan eksiklikleri giderme gibi bir imkân ve özeliği mevcuttur. ${ }^{8}$ Zira materyaller örgün eğitime ilaveten yaygın eğitim boyutuyla da dil gelişimine imkân sağlar. Zaman ve mekân üstü sunduğu imkânlarla dil gelişimi bireysel çabalarla aralıksız sürdürülebilir. ${ }^{9}$

Çeşitlilik açısından materyaller, hitap ettiği duyulara göre farklılaşsa da basılı materyaller (özellikle kitaplar), geleneksel ve yaygın eğitim araçları olarak itibar görür. Basılı materyaller; bilgiyi defalarca tekrar etme imkânı tanıması, hedef kitleye bağımsız/bireysel şekilde kendini geliştirme fırsatı sunması, taşınmasının kolay olması, duyu organlarını harekete geçirebilme-

4 Rüşdi Ahmed Tu'ayme, Mahmud Kamil en-Nâka, el-Kitâbu'l-esâsî li-ta lîmi'l-lugati'l-'Arabiyye li'nnâtıkine bi-lugâtin uhrâ, 1. bs. (Mekke: y.y., 1983), 27-28.

5 İbrahim Kekevi, "Erenlerin Bağından Adlı Şiir Metni Üzerine Metindilbilimsel İnceleme”, (Yüksek Lisans Tezi, Pamukkale Üniv. Sosyal Bilimler Enstitüsü, Denizli 2015), 4.

6 Dilidüzgün, Şükran. "Türkçe Öğretiminde Metindilbilimsel Bağlamda Uygulamalı Bir Yaklaşım”, (Doktora Tezi, İstanbul Üniv. Sosyal Bilimler Enstitüsü, İstanbul 2008), 23.

$7 \quad$ Bkz. Özcan Demirel, Yabancı Dil Öğretimi; İlkeler, Yöntemler, Teknikler, 2. bs. (Ankara: Usem Yayınları, 1990), 24,68, 87, 88.

8 Ron Howard, Gillian Brown, Teacher Education for Languages for Specific Purposes, (Clevedon: Multilingual Matters, 1997), 6; Vivian Cook, Second Language Learning and Language Teaching, 4. bs. (London: Hoder Education an Hachette UK Company, 2008), 139.

9 Jocelyn Howard, Jae Major, "Guidelines for Designing Effective English Language Teaching Materials", The TESOLANZ Journal, 12/1 (trsz.): 105. 
si, ulaşılabilirliği, maliyeti ve sağlık açısından daha uygun olması gibi pek çok avantaja sahiplerdir. ${ }^{10}$

Eğitimcilerden kimisi kendi hazırladığı notlarla eğitim faaliyetlerini sürdürmeyi tercih edebilir. ${ }^{11}$ Ancak bu uygulamanın oldukça meşakkatli olması sebebiyle de genellikle piyasada bulunan hazır materyallerin kullanımı yaygındır. Piyasada mevcut bulunan eserlerin çoğunluğu Arap dışı unsurlarca oluşturulur. ${ }^{12}$ Dünya üzerinde Arapça öğretiminin yürütüldüğü ülkeler arasında materyal basımının en düşük oranda kaldığı ülke ise Türkiye olmuştur. ${ }^{13}$ Zamanla bu durum aşılmış ve hatırı sayılır miktarda materyal telif edilmiştir. Bu tür kitapların hazırlanmasında -belli oranda- ticari saik/kaygılar güdülebilmektedir. ${ }^{14}$ Sonuç itibariyle basım faaliyetlerinin son derece kolaylaştığı günümüz eğitim sisteminde gelişi güzel materyal tasarımını dizginleyecek ortak değerler etrafında buluşulması acil bir ihtiyaçtır.

\section{Materyal Tasarlamada Dikkat Edilmesi Gereken İlkeler}

Arapça okuma dil becerisine yönelik materyal tasarımında dikkat edilecek ilkeler bu başlık altında ele alınacaktır. Metin kitapları dışında okuma becerisinin temel bileşenlerinden olan kelime ve gramer öğretimi adına diğer yardımcı materyallere de (kelime kartı vb.) bu bağlamda değinilecektir.

\section{A. Özgün Metinlerden Faydalanmak}

Metinlerin oluşumu belli bazı şekillerde gerçekleşir. Mevcut bir metni revize etmek veya ilk baştan yazmak yapılan en yaygın uygulamalardandır. ${ }^{15}$ Metnin oluşum şekli nasıl olursa olsun dikkat edilmesi gerekli temel kaide özgünlük meselesidir. Günlük hayatı yansıtan hikâye, roman ve şarkı-

10 Melek Çakmak, "Yabancı Dil Öğretimi”, Konu Alanı Ders Kitabı İnceleme Kılavuzu, der. Ayşegül Ataman, (Ankara: Nobel Yayın Dağıtım, 2001), 5; Erdal Ceyhan, Birol Yiğit, Konu Alanı Ders Kitabı İncelemesi, (Ankara: Anı Yayıncılık, 2003), 18-19; Abdurrahman Kılıç, Serdal Seven, Konu Alanı Ders Kitabı İncelemesi, 7. bs. (Ankara: Pegem A Yayıncılık, 2008), 18-19, 38-39.

11 Howard ve Major, "Guidelines for Designing Effective English Language Teaching Materials", 101.

12 Nazan Ertürk, "Türkiye'de Arapça Öğretimi Açısından 'İmam Hatip Liseleri Yeni Programa Uygun Arapça' Adlı Ders Kitabı Serisinin Değerlendirilmesi”, (Yüksek Lisans Tezi, Gazi Üniv. Eğitim Bilimleri Enstitüsü, Ankara 2004), 46.

13 Ayrıntılı bilgi için bkz. Tu'ayme ve en-Nâka, el-Kitâbu'l-esâsî li-ta 'limi'l-lugati'l- 'Arabiyye li'n-nâtıkîne bilugâtin uhrâ, 75.

14 Leslie E. Sheldon, ELT Textbooks and Materials: Problems in Evaluation and Development, y.y.: Modern English Publications, 1987), 1; Jocelyn Howard, Jae Major, “Guidelines for Designing Effective English Language Teaching Materials”, The TESOLANZ Journal, 12/ (tsz.): 101.

15 Hutchinson ve Waters, English for Specific Purpoes: A learning-Centred Approach, 96; Ayten Şahin, “Avrupa Dil Gelişim Dosyası Bağlamında Yabancı Dil Olarak Türkçe Öğretiminde Okuma Becerisini Geliştirmeye Yönelik Malzeme Oluşturma”, (Yüksek Lisans Tezi, Dokuz Eylül Üniv. Eğitim Bilimleri Fakültesi, İzmir 2010), 101. 
lar birer özgün yapıttır. Öte yandan gramer ve içerik bakımından kolaylaştırma ve sadeleştirme faaliyetlerine maruz kalmış metinler özgünlüğünü yitirmişlerdir. ${ }^{16}$ Dilin kendi doğal yapısından bu şekilde uzaklaşmasıyla yabancı dil öğrenme zevki köreldiği gibi öğrenme yetisi daha güç hale gelecektir. ${ }^{17}$ Zira dilin doğasına yapılan her müdahale, materyalin bağlamsal bütünlüğünü zedelerken hedef kitlenin güdülenmesine engel olmaktadır. ${ }^{18}$

Arapça öğretim materyallerinin tasarımı, ana dili Arapça olmayanlar, ana dili Arapça olanlar ya da her iki unsurun birlikteliğiyle yürütülebilir. Arapçayı sonradan öğrenen kimselerin katkı sağladığı materyal tasarımında, Arapçayı sonradan öğrenme ve tecrübeli olma gibi avantajlar söz konusudur. Buna karşılık sahip olunan ana dilin Arapçadan farklı oluşu, Arap dil mantığına uymayan yapaylıkların materyalde kullanılması ihtimaline sebebiyet verecektir. ${ }^{19} \mathrm{O}$ yüzden ana dili Arapça olan ve Arap dili mantığına göre düşünen kimselerin materyal tasarımında bulunmaları kaçınılmazdır.

Günümüz eğitim siteminde asli yapıları müdahaleye maruz kalmış çok fazla metin, okuma becerisi faaliyetlerinde kullanılmaktadır. Bu durum Arapça öğrenen hedef kitleler üzerinde Arapçaya karşı hoşnutsuzluk ve isteksizlik, kendilerine karşı ise güvensizlik hissi duymalarına neden olmaktadır. Sonuç itibariyle okuma metinlerinin özgün olma mecburiyeti söz konusudur.

\section{B. Görsel Araç-Gereçlerden Yararlanma}

Materyal, görsellik bakımından eğitim faaliyetlerinde güdülenmeyi etkilemektedir. ${ }^{20}$ Anlatılan konuların içeriği, dil öğrenme faaliyetinin ana temasını oluşturur. Ancak içeriğin sunulma şekli de izlenmede azımsanmayacak öneme sahiptir. Gerekli yerlerde kullanılacak özet ve projeksiyon mahiyetindeki tablo, resim, sembol ve şekiller, kodlama ve çağrışım yetisini

16 Brian Tomlinson, Materials Development in Language Teaching, 2. bs. (Cambridge: Cambridge University Press, 2011), Giriş/IX.

17 Berrin Uçkun, Zişan Onat, "Yabancı Dil Kitaplarında Özgün Metin ve Özgün Görev Kullanımının Önemi: Bir Kitap İncelemesi", Gaziantep Üniversitesi Sosyal Bilimler Dergisi, $7 / 1$ (2008): 149.

18 Eyyup Coşkun, "İlköğretim Öğrencilerinin Öyküleyici Anlatımlarında Bağdaşıklık, Tutarlılık ve Metin Elementleri", (Doktora Tezi, Gazi Üniv. Eğitim Bilimleri Enstitüsü, Ankara 2005), 249; Țu 'ayme ve enNaka, el-Kitâbu'l-Esâsî li-Ta 'limi'l-Lugati'l- Arabiyye li'n-Nâtı̣kine bi-Lugâtin Uhrâ, 64; Howard ve Major, “Guidelines for Designing Effective English Language Teaching Materials", 106.

19 Tu 'ayme ve en-Nâka, el-Kitâbu'l-esâsî li-ta 'lìmi'l-lugati'l- 'Arabiyye li'n-nâtıkîne bi-lugâtin uhrâ, 71-72.

20 Taha-Thomure, "The Status of Arabic Language Teaching Today", 189; Reyhan Tanın, "Yabanc1 Dil Olarak Türkçe Öğretiminde Sözcük Bilgisi ve Öğretimi”, (Yüksek Lisans Tezi, İstanbul: İstanbul Üniversitesi Sosyal Bilimler Enstitüsü, 2004), 61. 
kuvvetlendirecek, bilgiye kısa yoldan ulaşmaya yardımcı olacaktır. ${ }^{21}$ Özellikle dil öğrenme gibi uzun soluklu öğrenme sürecinin henüz başındakilere hitaben metinlerde bilinmeyen sözcüklerin sunumunda görsellerden faydalanılabilir. ${ }^{22} \mathrm{Bu}$ sayede çok fazla bilinmeyenle karşı karşıya kalan hedef kitlenin psikolojik açıdan yıpranması ve dikkat bozukluğu yaşaması ihtimali minimize edilecektir. ${ }^{23}$

\section{Sözcük Listesi ve Metin Çevirisi}

Okuma parçalarının hedef kitle tarafından bilinmeyen kelimeleri barındırması gayet olağandır. Dil seviyesi başlangıç düzeyinde olan kişilerin yaşayacağı ümitsizlik ve çaresizlik duygusu, çok daha kalıcı olumsuzluklara sebebiyet verebilir. Bu tür durumlara karşı tahmin etme stratejisinden faydalanmak gerekir. Ancak gerek tahmindeki başarısızlıklar gerekse olası zaman kayıpları tahmin mekanizmasını işlevsiz hale getirebilir. ${ }^{24}$ Ülkemizde alışık olunan kelime-kelime tercüme mantığı, okuma parçalarının genel manasının kavranması yerine bilinmeyen kelimelere odaklanmaya neden olmaktadır. ${ }^{25}$ Sıklıkla duraksamaların yaşanacağı bu tür okumalarda eğitimin devamlılığı sürdürülebilir değildir. Bu sebeple bilinmemesi muhtemel sözcüklerin manalarının liste halinde sunulması pedagojik bir ihtiyaçtır. Her bir okuma parçası akabinde bulunacak münferit sözcük listelerine ilaveten kelime listesinin tamamının tek bir başlık altında materyalin en son bölümüne eklenmesinde yarar vardir.

Metin çevirileri, okuyucunun anlamindan emin olmadığı yerlerde özgüven inşası sağlamasına yardımcı olur. Dil öğretim materyallerinin bazılarında ana metin ve tercümeleri yan yana (karşılıklı gelecek şekilde) sunulabilmektedir. Arapça öğretiminde böylesi bir tasarım, pratikliği bakımında

21 Benjamin S. Bloom, Taxonomy of Educational Objectives: The Classification of Educational Goals: Handbook 1 Cognitive Domain, (USA: Longmans, 1956), 3; Veysel Sönmez, Öğretim İlke ve Yöntemleri, 2. bs. (Ankara: Anı Yayınları, 2008), 69; Nazan Ertürk, "Türkiye'de Arapça Öğretimi Açısından 'İmam Hatip Liseleri Yeni Programa Uygun Arapça' Adlı Ders Kitabı Serisinin Değerlendirilmesi”, (Yüksek Lisans Tezi, Gazi Üniv. Eğitim Bilimleri Enstitüsü, Ankara 2004), 37-38; Sönmez, Öğretim İlke ve Yöntemleri, 67.

22 Mehmet Zeki Aydın, “Arapçayı Nasıl Öğretelim?”, Din Öğretiminde Yeni Yaklaşımlar, der. Mualla Selçuk, (İstanbul: Mili Eğitim Bakanlığı, 2000), 53-59; Elif Çırpıcı Çiğdemi, "Yabancı Bir Dil Olarak Arapça Nasıl Öğretilir", Haziran 2015 Arapça ve Mesleki Arapça Mesleki Çalışma Tebliğleri, 22-24; Nesibe Duman, İlknur Çifci Tekinarslan, "Hikâye Haritası Yönteminin Hafif Düzeyde Zihinsel Yetersizliği Olan Öğrencilerin Okuduğunu Anlama Becerileri Üzerindeki Etkisi”, Özel Eğitim Dergisi, 8/1 (2007): 38; Onur Helvac1, “Okuma Ediniminde Bağlam İpuçlarının Sözcük Edinimine Etkisi”, (Yüksek Lisans Tezi, İstanbul: Yıldız Teknik Üniv. Sosyal Bilimler Enstitüsü, 2004), 22.

23 Helvacı, "Okuma Ediniminde Bağlam İpuçlarının Sözcük Edinimine Etkisi”, 15; Nur Yıldız, "Arapça Sözcük Öğretiminde Yapılan Uygulamalar: İlahiyat Fakültesi Örneği”, (Yüksek Lisans Tezi, İstanbul Marmara Üniv. Sosyal Bilimler Enstitüsü, 2009), 26-27.

24 Tanın, "Yabancı Dil Olarak Türkçe Öğretiminde Sözcük Bilgisi ve Öğretimi", 71.

25 Bostanc1, "Ürdün Üniversitelerinde Yabancllara Arapça Öğretimi”, 96-97. 
gayet uygun olsa da hedef kitlenin karşılaşacağı en küçük zorlukta kendisine sığınılacak bir mercie dönüşebilir. Böylesi bir durumla karşılaşmamak için dil yeterlilik seviyesine göre farklı manevralar geliştirmekte yarar vardır. Bu kapsamda başlangıç düzeydeki materyalde sayfa ikiye bölünerek üst bölüme ana metin, alt kısma ise çeviri konabilir. Orta düzey materyalde, metin çevirisi ana metin akabindeki bilinmeyen kelime listesinin sonrasında bulunabilir. İleri seviyedeki metinlerde ise materyalin en sonunda bulunan kelime listesi ardından metin çevirileri verilebilir.

\section{Flaş Kartlar ve Teknolojik İmkânlardan Yararlanma}

Yabancı bir dil öğrenmeye başlandığında yapılacak ilk eylem, hedef dildeki temel sözcük bilgisine belli oranda hâkimiyet kurmak olacaktır. Zira yeterli sözcük haznesine sahip olmayan kimseler, okuduğunu anlamada büyük problemler yaşayacakları gibi henüz başında oldukları dil öğrenme sürecini çok geçmeden sonlandırma riskiyle karşı karşıya kalabilirler. Bu tarz olumsuzluklarla karşılaşmamak adına hedef kitlenin ihtiyaçları mukabilinde hazırlanacak sözcük listeleri asli bir ihtiyaçtır. ${ }^{26}$

Yabancı dil öğretimi kapsamında hazırlanan materyallerde kelime listeleri, belli bazı şekillerde uygulanmaktadır. Bunlar, ana hatlarıyla şu şekildedir; $; 2$

1. Yalnızca hedef dile ait sözcüklerin listesi.

2. Hedef dildeki kelimelerin anadildeki karşılıklarının yer aldığı liste.

3. Fiil ve isimlerin zaman, cinsiyet ve adet varyantlarının bulunduğu liste.

4. Fiillerin morfolojik değişime uğradığı sözcük listesi.

5. Kelimelerin eş ve karşıt manalarıyla listelendiği liste.

Bu tür uygulamalar arasında bütünleşik bir kelime listesi yapısı oluşturulabilir. Buna göre; sözcüklerin morfolojik değişimdeki halleri ile ana dildeki anlamları esas alınarak kelime listeleri oluşturulmalıdır.

Modern dönemde ulaşılan teknolojik yenilikler, eğitim alanında da pek çok kolaylığı beraberinde getirmiştir. ${ }^{28}$ Yaygın eğitim ağ1 gelişip geniş-

\footnotetext{
Virginia French Allen, Techniques in Teaching Vocabulary, (Oxford: Oxford University Press, 1983), 108.

Tu 'ayme ve en-Nâka, el-Kitâbu'l-esâsî li-ta 'limi'l-lugati'l- 'Arabiyye li'n-nâtıkîne bi-lugâtin uhrâ, 107.

Bkz. Howard ve Major, "Guidelines for Designing Effective English Language Teaching Materials", 104; Marc Prensky, "What Can You Learn from a Cell Phone? Almost Anything!", Harnessing the Potential of ICT for Education: A Multistakeholder Approach, ed. Bonnie Bracey, Terry Culver, (New York: United Nations ICT Task Force, 2005), 271-279.
} 
lemiş, akıllı telefon ve bilgisayarlar dil öğrenme faaliyetlerinde ciddi avantajlar sunma potansiyeline ulaşmışırı. ${ }^{29}$ Geleneksel yapıya sahip kelime kartları, sözcük öğrenmede önemini korumakla beraber özellikle akıllı telefonların yaygınlaşmasıyla sözcük öğrenmek çok daha yaygın ve ulaşılabilir bir hal almıştır. $^{30}$

Öğrenme ve teknoloji kavramları, geçmişte birbirine karşıt iki imgeyi çağrıştırmaktaydı. Özellikle genç bireylerin vazgeçilmezi olan elektronik cihazların kullanımlarının nasıl kısıtlanacağından ziyade eğitime nasıl kazandırılmaları gerektiği meselesi daha yapıcı bir eylem planı olacaktır. ${ }^{31}$ Sunmuş olduğu hareket kabiliyetiyle gündelik yaşamda boş vakit olarak nitelendirilecek (toplu taşıma ulaşımı esnası vb.) zaman dilimlerinde dil öğrenmeye ciddi katkılar sağlayacaktır. ${ }^{32} \mathrm{Bu}$ bağlamda, mobil uygulamalarda yukarıda belirtilen ölçütler dâhilinde kelime listeleri tasarlanabilir.

\section{E. Arapça Ortak Kelime Özü}

Kullanımı standart hale gelen sözcük grupları (Common Core), insanlığın sahip olduğu dil çeşitliliğii içerisinde ortak bir özellik olarak akla ilk gelen şeylerdendir. Dillerin mantığı, birbirinden farklılaşan belli temel kurallar ve sözcükler üzerine inşa edilmiştir. Dil öğrenme amacı fark etmeksizin

29 Javad Gholami, Ghader Azarmi, “An İntroduction to Mobile Assisted Language Learning”, International Journal of Management in Education, 2/8 (2012): 2; Muhammed Seyfülislam, "Ta 'limu'l-Lugati'l-'Arabiyye Beyne'r-Ru' ye'l-Fenniyye ve'n-Nazariyyâti'l- 'İlmiyye", Âfâku's-Sekâfe ve't-Turas, (2013): 30; Murat Saran, Kürşat Çağıltay ve Gölge Seferoğlu, "Use of Mobile Phones in Language Learning: Developing Effective Instructional Materials", Fifth IEEE International Conference on Wireless, Mobile and Ubiquitous Technologies in Education - WMUTE, 23-26 Mart 2008 Beijing, (Beijing: 2008), 43; Mohamed Sarrab, Laila Elgamel ve Hamza Aldabbas, "Mobile Learning (M-Learning) and Educational Environments", International Journal of Distributed and Parallel Systems (IJDPS), 3/4 (2012): 31-35; Glenn, Stockwell, "Vocabulary on the Move: İnvestigating an İntelligent Mobile Phone-Based Vocabulary Tutor", Computer Assisted Language Learning, 20/4 (2007): 365; Hnin Pwint, "Learning on the Move: The Use of Mobile Technologies for Language Skill Development", Executive Journal, 34/1 (2014): 99.

30 Emrah Baki Başoğlu, “Cep Telefonu ve Sözcük Kartı Kullanan Öğrencilerin İngilizce Sözcük Öğrenme Düzeylerinin Karşılaştırması”, (Yüksek Lisans Tezi, Zonguldak Karaelmas Üniv. Sosyal Bilimler Enstitüsü, Zonguldak 2010), 50.

31 Laura Naismith, Peter Lonsdle, Giasemi Vavoula ve Mike Sharples, Literature Review in Mobile Technologies and Learning, (Birmingham: Futurelab Series, 2004), 36; Prensky, "What Can You Learn from a Cell Phone? Almost Anything!”, 277-279; Seyfülislam, “Ta 'limu'l-Lugati'l-'Arabiyye Beyne'r-Ru'ye'lFenniyye ve'n-Nazariyyâti'l- 'İlmiyye", 21.

32 Agnes Kukulska-Hulme ve Shield Lesley, "An Overview of Mobile Assisted Language Learning: From Content Delivery to Supported Collaboration and Interaction", European Association for Computer Assisted Language Learning, 20/3 (2008): 271; Agnes Kukulska-Hulme, "Will mobile learning change language learning?", European Association for Computer Assisted Language Learning, 21/2 (2009): 157-158; Saran, Çağıltay ve Seferoğlu, "Use of Mobile Phones in Language Learning: Developing Effective Instructional Materials", 39; Gunther Dohmen, "Yetişkinlerin Eğitimi İçin Yeni Bulgular", çev. İlhan Tomanbay, Ĕgitim ve Bilim, 2/12 (1978): 24. 
her dil kapsamı ve alanına hitap edebilen temel yapı birimleri mevcuttur. ${ }^{33}$ Diğer bir ifadeyle, bir dili klasik literatürü takip etmek amacıyla öğrenenlerle modern formda konuşma amacıyla öğrenenler, gramer ve sözcük bilgisinde ortak paydada buluşacaktır. Bu bağlamda öğrenilme amacı her ne olursa olsun hedef dildeki ortak sözcük ve dilbilgisi haznesinin tespiti kaçınılmazdır. ${ }^{34}$ Farklı amaçlarla öğrenilen dilin yeterlilik seviyesi ilerledikçe dilin öz yapısında doğal farklılaşmalar artacaktır. ${ }^{35}$

Okuma becerisine yönelik yapılacak okumalar hedef dil özünün yeterli derecede bilinmesini gerektirmektedir. Bu sebeple dilin özünü oluşturan temel yapılar öncelikle başlangıç seviyesindeki metinlerde bulunmalıdır. Aksi takdirde hedef kitlenin güdülenmesi olumsuz yönde etkilenir.

Tespit edilecek bu yapılar, adeta Arapçanın temel taşlarının inşasına imkân sağlayacaktır. Arap dili mantığının kavranması yolunda temelin sağlam atılması hayati önemi haizdir. Dil temelinin inşasında yaşanan ihmaller, çamura yaslanmış bir merdivene batma tehlikesine aldırış etmeksizin tırmanmaya benzer. O yüzden dilin temel yapılarının öğrenilmesi ileri seviyede dil yeterliliğinin teminatıdır. ${ }^{36} \mathrm{Bu}$ konunun bir devamı niteliğindeki bilgiler bir sonraki başlık altında ele alınacaktır.

\section{F. Seviyeye Uygun Metin Tasarımı}

Eğitimin her çeşidinde tedricilik, pedagojinin temel esasıdır. Eğitim planlama ve tasarımlarında hitap edilen kitlenin seviyesi, içeriğin oluşumuna bizatihi etki etmektedir. Aynı şekilde eğitim sorunsallarında da içgörüsel uygulamalardan ziyade seviyelere uygun çözüm önerilerine ihtiyaç vardır. ${ }^{37}$ Dil öğrenme, hayat boyu devam eden uzun süreli bir süreç olduğundan,

33 Mariel Bloor, Thomas Bloor, Language for Specific Purposes: Practiice and Theory. CLCS Occasional Paper No. 19., (Dublin: Trinity Coll Centre for Language and Communication Studies, 1986), 19.

34 John Flowerdew, Matthew Peacock, Research Perspectives on English for Academic Purposes, 1. bs. (Cambridge: Cambridge Universty Press, 2001), 16-18; Peter Master, "ESP Teacher Education in the USA", Teacher Education for Languages for Specific Purposes, ed. Ron Howard, Gillian Brown, (Clevedon: Multilingual Matters, 1997), 27-28; Hünkar Korkmaz, "Çoklu Zeka Kuramı Tabanlı Etkin Öğrenme Yaklaşımının Öğrenci Başarısına ve Tutumuna Etkisi", Ĕ̆itim ve Bilim, 26/119 (2001): 72.

35 T. Saragi, I. S. P. Nation ve G. F. Meister, "Vocabulary Learning and Reading", System, 6/2 (1978): 72; bkz. Atagül Yasemin Yılmaz, "Yabancı Dil Olarak Türkçe Öğretiminde Atasözleri ve Deyimlerin Sıklık Analizi", International Periodical For The Languages, Literature and History of Turkish or Turkic, 10/7 (2015), 1021-1035.

36 Bloor ve Bloor, Language for Specific Purposes: Practice and Theory. CLCS Occasional Paper No. 19., (Dublin: Centre for Language and Communication Studies, 1986), 13-18.

37 Nuray Senemoğlu, Gelişim Öğrenme ve Öğretim: Kuramdan Uygulamaya, 13. bs. (Ankara: Gazi Kitapevi, 2005), 132. 
karşılaşılan zorluklar eğitimde devamlılık sağlamayı engelleyebilir. Bu bağlamda materyallerin zorluk derecesinin kademeli olması gayet önemlidir. ${ }^{38}$

Önceki bölümde de üzerinde durulduğu üzere Arap dili öğrenmede öncelikli eylem planı Arapçanın öz yapısının öğrenilmesidir. Ardından hedef kitle ihtiyaçlarının gözetildiği (okuma becerisi özelinde) metinler dizayn edilmelidir. ${ }^{39}$ Maruz kalınan girdiler ile harcanan süre ve bilgi niceliği arasında negatif bir ilişki mevcuttur. Dilsel bilgilerin nitelik bakımından daha köklü şekilde işlemesi planlı bir sürece yayılarak gerçekleşebilecektir. ${ }^{40}$

Arapça materyal tasarımında takip edilecek kademeliği, -aşağıdaki şekilde- kelime ve dil bilgisi eksenli mütalaa etmek de mümkündür.

\section{Metinde Bulunması Gereken Sözcük Oranı}

Okuma becerisinde maddi eylem yapısını üstlenen unsur gözdür. Göz hareketleri, metnin satırlarındaki çizgiler doğrultusunda hareket etmeksizin bazı duraksama ve sıçramalar yaşar. Bu eylemlerde gözün görüş alanı kısıtlıdır ve bu mesafe dâhilindeki kelimeler toplamı görme genişliği kavramıyla ifade edilir. Görme genişliği, hedef kitlenin dil yeterliliğine göre 6-20 harf aralığında değişir. ${ }^{41}$ Okuma becerisini görme genişliği ve okuma hızı dışında etkileyen diğer bir temel yapı da bilinmeyen kelimelerdir. Bilinmeyen kelimeler, dilin söz ögeleri olarak tanımlanan sözcük, bileşik cümle veya deyimleri ifade eder. ${ }^{42}$

Bazı dilciler, okuyucuların metinde bilemedikleri kelime ortalamasını tespit etmeye çalışmıştır. Üzerinde uzlaşılan ortalamaya göre azami bakımdan bilinmeyen kelime sayısı, metnin toplam kelime sayısından 3/1 oranına tekabül edebilir. Üst sınır olarak ifade edilen bu oranların alt sınırı ise metinlerde sayfa başı birkaç sözcüğe düşmektedir. Bu oranlar belirlenirken bilinmeyen sözcüklerin anlamlarının metnin bağlamından hareketle de tespit

\footnotetext{
38 Tu 'ayme ve en-Nâka, el-Kitâbu'l-esâsî li-ta 'limi'l-lugati'l- 'Arabiyye li'n-nâtıkîne bi-lugâtin uhrâ, 31-32; TahaThomure, "The Status of Arabic Language Teaching Today", 189; Reyhan Tanın, "Yabancı Dil Olarak Türkçe Öğretiminde Sözcük Bilgisi ve Öğretimi", 189.

39 Tu'ayme ve en-Nâka, el-Kitâbu'l-esâsî li-ta 'limi'l-lugati'l- 'Arabiyye li'n-nâtıkîne bi-lugâtin uhrâ, 99-100.

40 Rob Waring, Misako Takaki, "At What Rate Do Learners Learn and Retain New Vocabulary From Reading a Graded Reader?", Reading in a Foreign Language, 15/2 (2003): 153-155.

41 Sabri Koç, Güneş Müftüoğlu, "Dinleme ve Okuma Öğretimi", Türkçe Öğretimi, der. Seyhun Topbaş, (Eskişehir: Anadolu Üniversitesi Yayınları: Açıöğretim Fakültesi Yayınları, 1998), 62.

42 Richard R. Day, "Selecting a Passage for the EFL Reading Class", ELT FORUM, 32/1 (1994): 20.
} 
edileceği göz önünde bulundurulmuştur. ${ }^{43}$ Materyalde bilinmeyen unsurların niceliksel yoğunluğu da hedef kitlenin dil seviyesine göre belirlenecektir.

Kimi dilcilere göre ise sağlıklı bir tahmin mekanizmasına sahip olmak için metin içeriğinin \%95 seviyesinde bilinen karakter yoğunluğuna sahip olması gerekir. İçeriği roman tarzı genel bir okuma alanına hitap eden metinlerdeki kelime sayısı da 3000-5000 aralığında olacaktır. Teknik ve bilimsel içerikteki metinlerin sahip olacağı kelime haznesinin bilinirlik kat sayısı diğer alanlara göre daha düşük seviyelerde seyredebilir. Akademik türde metinlerin anlaşılabilmesi için hedef dilde bilinmesi gerekli olan kelime sayısı da dilcilerce tartışılmıştır. Bu kapsamda metin içerisinde bulunan tüm sözcüklerden \%95 oranına sahip olan ve en az 5000 kelimeye karşılık gelen bir ortalama uygun görülmüştür. Bilinen sözcük oranının \%90 seviyelere gerilediği metinlerde ise bilinmesi gerekli sözcük alt sınırı 3300 olmaktadır. Dünya üzerinde öğretimi global olan İngilizce için akademik literatür takibinde sahip olunması kaçınılmaz kelime dağarcı̆̆ı 500-3000 dolaylarındadır. Bu oranı savunan düşünce tarzı, hedef dili doğru şekilde anlamak için yeterli olmadığı gerekçesiyle eleştirilmiştir. Bu sebeple sağlıklı bir anlam dünyasına ulaşabilmek için 5000 kelimenin bilinmesi daha muteber bir oran olmuştur. ${ }^{44}$

Sadeleştirmeye maruz kalmayan metinlerin anlaşılmasında bilinmesi kaçınılmaz sözcük sayısı 3600 olarak belirlendiğinde metinde anlamı bilinmeyen kelimelere rastlamak oldukça olasıdır. ${ }^{45}$ Yabancı dili öğrenmeye yeni başlayan ve dil yeterliliği başlangıç seviyesinde olanların 2000 kadar kelimeyi bilmesi ön görülür. ${ }^{46}$ Michael West'in bakış açısıyla kullanımı en sık kelimelerin sayısı genel amaçlardaki metinlerde 2284, akademik amaçlarda ise $574^{\prime}$ tür. ${ }^{47} \mathrm{Bu}$ anlamda metin içeriğinin anlattığı konu türü ve çeşitliliği kelime oranını tayinde kilit rol oynar.

İnilizce gibi Arap dili de kelimelerin morfolojik özellikleri bakımından birbirine benzer yapıda dillerdir. Arap dilinin kök yapı sınırı 11500 olarak tespit edilmiştir. ${ }^{48}$ Ancak kök yapının çok güçlü bir türetme sistemiyle

43 Waring ve Takaki, "At What Rate Do Learners Learn and Retain New Vocabulary From Reading a Graded Reader?", 153.

44 Batia Laufer, "What percentage of text-lexis is essential for comprehension?", Special Language: From Humans Thinking to Thinking Machines, ed. Christer Lauren, Marianne Nordman, USA: Multilingual Matters, 1989, 316-320; Waring ve Nation, "Second Language Reading and Incidental Vocabulary Learning", Museum Tusculanum Press: The University of Copenhagen, 4/1 (2004): 12.

45 Saragi, Nation ve Meister, "Vocabulary Learning and Reading", 72.

46 Tanın, "Yabancı Dil Olarak Türkçe Öğretiminde Sözcük Bilgisi ve Öğretimi", 43.

47 Michael West, A General Service List of English Words, (London: Longman, 1953).

48 Muhammed Ṭayyibî en-Neccâr, el-Lugatü'l- 'Arabiyyetü'l-Mu 'âsıra, y.y., tsz., 247-251. 
zenginleştiği ciddi bir sözcük birikimi mevcuttur. Bu sebeple 5000 kelimenin bilinirliği genel kapsamlı okumalar için kabul edilebilirdir. Ancak bu oran artabileceği gibi daha da aşağılara inebilir. Özellikle Klasik Arapça olarak nitelendirilen ve modern dilde kullanılmayan sözcüklerin yer aldığı metinlerde bu oranın yeterli olmadığı görülecektir. Bu tür okumalarda sözlük vb. yardımcı materyallerden destek almak kaçınılmazdır.

Evrensel bir kategori olarak diller, öğrenilmeleri ve yeterlilikleri bakımından başlangıç (Beginning), orta (Intermediate) ve ileri (Advanced Level) düzeylere ayrılır. ${ }^{49} \mathrm{Bu}$ aşamalardan her biri önem arz etmekle beraber başlangıç seviyesi, diğer seviyelere nazaran ayrı bir öneme haizdir. Henüz dil öğrenmenin başındakilere hitaben takip edilecek özgün hikâye serileri kayda değer gelişime yarar sağlayacaktır. Bu seviyede metinlerde 50-200 arası sözcük ortalamasında metin içeriği dizayn edilebilir. ${ }^{50}$ Ardından bu oran, hikâyelerin ilerleyen serilerinde aşama-aşama artırılarak hedef dil mantığ1 metinler üzerinden öğrenilebilecektir. Günümüz itibariyle Türkiye'de basılan Arapça hikâye serilerinin sayısı her geçen gün artmakta ve bu alandaki ihtiyaç da doldurulmaktadır.

\section{Metindeki Gramer Bilgisinin Tedriciliği}

Okuma becerisinin kaynağı olan yazılı dil, sadece sesli harf karakterlerini bünyesinde barındırmasıyla pedagojik bir zorluğa imkân sağlamaktadır. Zira Arapça, yazı dilinde sesli harfleri itibara almayan Fenike alfabe sistemini benimsemiştir. ${ }^{51} \mathrm{Bu}$ sebeple sesli harflerin yerini tutması adına belli bazı şekiller (hareke) ihdas edilmiştir. Ancak Arapça yazı dilinde asıl olan iletişim, sesli harfe yer vermeyen formatta yürütülür. Böylesi bir zorluğa cümledeki kelimelerin sentaksına ve dolayısıyla semantiğine etki eden irab olgusu da eklenmelidir. Bu açıdan Arap dili grameri, eğitsel bakımdan diğer dillerde rastlanılmayan bazı zorlukları haizdir. Bu bakımdan Arapça öğrenmeye karşı sergilenen olumsuz yaklaşımlar eğitim faaliyetinin sonlandırılmasına kadar varabilmektedir. Gerek Arapçanın dil yapısı gerekse eğitimcilerden ötürü hedef kitlenin eğitimden geri durması yapıcı bir reaksiyon

\footnotetext{
49 Tu 'ayme ve en-Naka, el-Kitâbu'l-esâsî li-ta 'limi'l-lugati'l- 'Arabiyye li'n-nâtıkîne bi-lugâtin uhrâ, 114.

50 Şafak Kaman, “Akıcı Okuma Stratejilerini Kullanmanın İlköğretim Üçüncü Sınıf Öğrencilerinde Okuma Becerisini Geliştirmeye Etkisi”, (Yüksek Lisans Tezi, Ahi Evran Üniv. Sosyal Bilimler Enstitüsü, Kırşehir 2012), 24; Uçkun ve Onat, "Yabancı Dil Kitaplarında Özgün Metin ve Özgün Görev Kullanımının Önemi: Bir Kitap İncelemesi", 152; Erol Barın, "Yabancılara Türkçenin Öğretilmesinde Bir Metod Denemesi", (Yüksek Lisans Tezi, Gazi Üniversitesi Sosyal Bilimler Enstitüsü, Ankara 1992), 86.

51 Bkz. Fatma Erkman Akerson, Türkçe Örneklerle Dile Genel Bir Bakış, 2. bs. (İstanbul: Multilingual, 2008), 50-56.
} 
olmayacaktır. ${ }^{52}$ Esasen harekesiz metinlerin günümüzde büyük bir problem olarak görülmesinde materyallerin tasarlanma keyfiyetinin de etkisi vardır.

Hareke ve irab bakımından Arapça metinlerde belli bazı uygulamalar mevcuttur. Bunlar şu şekildedir; 53

1. Metnin tüm karakterleri harekelenir ya da harekelenmez.

2. Ana metin harekelenmeyip kelime listesinde yer alan sözcükler harekelenir.

3. Son uygulamada ise okuyucunun dil seviyesine yönelik gerçekleştirilecek harekeleme faaliyetidir. Metinlerin başlangıç seviyesinde tamamen, orta seviyede kısmi, ileri seviyelerde ise (mümkün oldukça) nadir harekelemeye başvurulur.

Üçüncü sırada zikredilen harekeleme çeşidi (kanaatimizce) pedagojik bakımdan en yararlı olanıdır. Böylesi bir uygulamada Arapça öğrenmeye henüz yeni başlayan kişilerin okudukları metinlerde hareke gibi tali bir unsura değil, ana temayı oluşturan metin içeriğine odaklanması sağlanacaktır. Orta seviyedeki okuyucular, Arap dilinde hatırı sayılır bilgi birikimine sahip kitleler olarak -Arapçanın asli yapısı olan- sessiz yazı sistemine tedrici faaliyetlerle geçecek ve harekesiz yazı diline uyum sağlayacaktır. İleri seviyelerde ise (istisnai durumlar hariç) ${ }^{54}$ metinlerin irabsız-harekesiz tasarlanıp okunması en pedagojik yöntem olacaktır.

\section{G. Sözcüklerin Bağlamdan Koparılmaması}

Arapça metin okumalarında bilinmeyen kelimelerle karşılaşmak son derece olağandır. Böylesi anlarda uygulanmak üzere stratejik eylem planlamalarının geliştirilmesi ve tespit edilmesi asli bir gerekliliktir. Bu bağlamda dil yeterliliği orta seviyede olan okuyuculardan başlamak üzere, metinlerdeki bilinmeyen kelimelerin olabildiğince bağlam içerisinde okunması gereklidir. ${ }^{55}$ Zira bağlamdan koparılan bilinmezler, gereğinden fazla ilgiye maruz kalabilmektedir. Oysa metinler, yazılı dilde kelimelerden daha kolektif ve ana yapıya sahip oluşumlardır. Okuyucuların anlamaya çalışacağı odak nokta metin olması gerekirken en küçük yapı birimlerinden bilinme-

Rahmi Yaran, Arapça'da İ'rab, 4. bs. (İstanbul: Rağbet Yayınları, 2016), 9.

Tu'ayme ve en-Nâka, el-Kitâbu'l-esâsî li-ta 'limi'l-lugati'l- 'Arabiyye li'n-nâtıkîne bi-lugâtin uhrâ, 90.

Arap dilinin sözcük yapısı çekimli olduğundan sesli harflerin belirtilmediği bazı durumlarda mananın birden fazla anlaşılması mümkündür. Bu tür durumlarda bağlam devreye girse de bağlamında yetersiz kalması mümkündür. Böylesi haller karşısında anlaşılırlığı çok anlamlı olan kelime/kelimelerin harekelenmesi gerekecektir.

55 Allen, Techniques in Teaching Vocabulary, 47-48. 
yenle karşılaşıldığında bu olgulara takılmamak gerekir. ${ }^{56}$ Aksi takdirde gerek metinde karşılaşılan bilinmezler gerekse kelime listeleri sıradanlaşarak metin okuma alışkanlığı geliştirememe problemi yaşanacaktır.

Bağlamdan yola çıkarak yapılan tahminler, kelimelerin bilinçaltına sızma ihtimali artırır. ${ }^{57}$ Yapılan bir araştırmada yaş ortalaması 13 olan kitleden yaklaşık 1000 kelimeden oluşan orta düzey bir metni okumaları istenmiştir. Bu yolla hedef kitlenin bağlam üzerinden kelime öğrenme başarılarının tespiti amaçlanmıştır. Araştırma sonucunda sözcüklerin doğru tahmin edilme oranı \%10-15 aralığında bulunmuştur. Ulaşılan bu veriye ek olarak başarının ardında istikrarlı eğitim etkinliklerinin yer aldığı da ayrıca vurgulananlar arasındadır. ${ }^{58}$

Bir diğer çalışma ise Felemenkçenin öğretimi hakkında yapılmıştır. 907 adet sözcükten oluşan bir metin hedef kitleye sunulmuş, okuyucuların bilmedikleri kelimeleri öğrenmede kayda değer başarısı tespit edilmiştir. ${ }^{59}$ Bu tür araştırma bulgularından hareketle denebilir ki, bilinmeyen sözcüklerin metin bağlamından koparılmayışı gerek mananın tahmini gerekse mananın uzun süreli belleğe aktarılmasını desteklemektedir. Tüm bunlara ek olarak kelimelerin metin bağlamından uzaklaştırılmaması ve böylece bilinen sözcüklerin pekiştirilmesi ulaşılacak kazanımlardan bir diğeridir. ${ }^{60}$

Kelime bilgisinin metin bağlamından koparılmış liste ve kartlar vasıtasıyla pekiştirilmesi pedagojik bir yaklaşım değildir. ${ }^{61}$ Ancak hedef dili yeni öğrenmeye başlayanlar, kelime kartlarını kullanarak temel düzeyde sözcük öğrenme işlemini gerçekleştirebilir. Buna ek olarak hikaye kitapları ile de dil gelişimi takviye edilebilir. ${ }^{62}$

Kelime ve bağlam ilişkisi ile alakalı üzerinde durulacak son mesele ise semantik kapsamlıdır. -Diğer tüm dillerde söz konusu olduğu gibi- Arapçada kelimelerin anlamları bağlam dairesinde ciddi şekilde farklılaşır. Bu

\footnotetext{
56 Abdullah Er, "Yabancı Dil Öğretiminde Okuma”, Kazım Karabekir Eğitim Fakültesi Dergisi, 12 (2005): 215.

57 Jahn H. Hulstijn, "Retention of Inferred and Given Word Meaning: Experiments in Incidental Vocabulary Learning", Vocabulary and Applied Linguistics, ed. Pierre J. L. Arnnaud, Henri Bejoint, (UK: Palgrave Macmillan, 1992), 114.

58 William E. Nagy, Patricia A. Herman, Richard C. Anderson, “Learning Words from Context”, Reading Research Quarterly, 20/2 (1985): 245-246.

59 Bkz. Hulstijn, "Retention of Inferred and Given Word Meaning: Experiments in Incidental Vocabulary Learning", 115-124.

60 Bkz. Nagy, Herman ve Anderson, “Learning Words from Context”, 233-252.

61 Tu ayme ve en-Nâka, el-Kitâbu'l-Esâsîli-Ta 'limi'l-Lugati'l- 'A rabiyye li'n-nâtıkîne bi-Lugâtin Uhrâ, 63.

62 Aslı Özlem Tarakçığlu, Hatice Kübra Tunçarslan, "The Effect of Short Stories on Teaching Vocabulary to Very Young learners (Aged 3-4-year): A Suggested Common Syllabus", Journal of Language and Linguistic Studies, 10/2 (2014): 67.
} 
durum bir isim olan صَاحِبُ ve bir fiil olan ضرب sözcükleri üzerinden şu şekilde anlatılabilir. ${ }^{63}$

\begin{tabular}{|c|c|}
\hline $\begin{array}{c}\text { Kelimesinin Bağlama Göre } \\
\text { Kazandı̆̆ı Manalar }\end{array}$ & Kelime/Cümle Örnekleri \\
\hline $\begin{array}{l}\text { Niteleme, bir sıfatı şahsında bulun- } \\
\text { durma }\end{array}$ & \\
\hline Aidiyet/sahiplik & -Ev sahibi \\
\hline Arkadaşlık & صاحبي Arkadaşım \\
\hline Yoldaşlik & \\
\hline Faydalanma & \\
\hline Hak etme & صاحِبُ الحمِِّّ-Hak sahibi \\
\hline Bölüşme & Aslan payı paydaş1 -صاحِب نَصيبِ الأسَد \\
\hline
\end{tabular}

\begin{tabular}{|c|c|}
\hline $\begin{array}{c}\text { Fiilinin Bağlama Göre Kazan- } \\
\text { diğg1 Manalar }\end{array}$ & Kelime/Cümle Örnekleri \\
\hline Cezalandirmak & ضرَب زيدُ عمرًا -Zeyd Amr'a vurdu. \\
\hline Anma & ضرَب الله مثلاً Allah örnek verdi. \\
\hline Kurma-İkame etmek & . ضرَب له قُبَّة \\
\hline Basma & اضرَب العُمْلة \\
\hline Tayin etme & $\begin{array}{c}ض \text { ضرَب له موِعِدا }- \text {-(Ona) randevu belirle- } \\
\text { di/verdi. }\end{array}$ \\
\hline (Rızık temini için) Uzaklara gitmek & - ضرَب في الأرْض Yürüdü/Seyahat yaptı. \\
\hline Hesaplama & 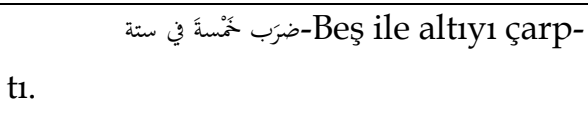 \\
\hline
\end{tabular}

Yukarıdaki örneklerde görüldüğü üzere sözcükler, dâhil oldukları cümle bağlamında oldukça farklı manalara evrilmektedir. Bağlama göre mananın çeşitlendiği gerçeğini göz ardı ederek okuma eylemlerinde tekdüze anlam arayışı, öğrencilerin özgürleşmesine set çekebilir. Diğer bir ifadeyle, metin çözümlemelerinde tek bir doğrunun ve doğru çevirinin varlığına

63 Temmam Hassan Ömer, el-Lugatu'l- 'Arabiyye ma 'nāhē ve mebnāhēe, 5. bs. (y.y.: 'Âlemu'l-Kutub, 2006), 323324. 
inanmak dil yeterliliğinin gelişmesini kısıtlayacaktır. Özellikle örgün kapsamda yürütülen Arapça metin okumalarında eğitimcilerin anlamsal çıkarımın sorgusuz ve alternatifsiz kabul etmemek gerekir. Hedef kitlenin kendisini geliştirebildiği duygusuna alışması için Arapçayı anlamada ve anlamlandırmada yanlış yapmaktan çekinmemelidir. Ayrıntılı tarzda öğretimi yapılan gramer bilgisinin pratikteki karşılı̆ıının yakalanamaması yukarıda işaret edilen durumu destekler niteliktedir. ${ }^{64}$

\section{H. Materyalin Fiziksel Görünümü ve Kullanım Kolaylığı}

Dil öğretim materyallerinin esas gayesi içerdikleri bilgilerle hedef kitlenin dil yeterliliğini geliştirmektir. Materyal içeriği beraberinde ihmal edilememesi gerekli bir diğer mesele de bilginin sunulma şeklidir. ${ }^{65}$ Eğitimcilerden pek çoğu, materyali tasarımdan ziyade muhteva bakımından önemser. Tasarım özelliklerini ifade eden baskı kalitesi, kâğıtların hamur çeşidi, hacim ve tasarım gibi meseleler ise teferruat olarak ikinci plana atılmaktadır. ${ }^{66} \mathrm{Bu}$ düşüncenin ileri noktalara varmasıyla eğitim materyalleri, tasarım itibariyle çekicilikten oldukça uzaklaşmaktadır. ${ }^{67}$

Bazı dilciler ise eserlerinin muhtevasına gösterdikleri önemin aynısını kitap tasarımına da yansitırlar. Bu uygulamalarda tasarımın muhtevaya öncelenmesi gerektiğini düşünenler de mevcuttur. ${ }^{68}$ Araştırmalar, (önemsiz bir ayrıntı gibi görünebilse de) renklerin eğitim faaliyetlerine etki eden özelliklere sahip olduğu sonucuna ulaşmıştır. Materyallerin tasarlanmasında da rastgele seçilecek renkler istenmeyen etkilere neden olabilir. ${ }^{69}$ Unutmamak gerekir ki bir yemeği kendisi yapan şey, yalnızca onun yapılma şekli ve lezzeti değil, ayrıca onun iştah kabartıcı tarzda sunulmasıdır. Okuyucuların okuma becerisine yönelik bakış açıları da bu şekildedir.70

64 Bkz. Ekrem Kalkan, “Avrupa Dilleri Ortak Çerçeve Programı Kapsamında Türkiye'de Yabancı Dil Öğretmeni Yetiştirme Politikaları”, (Yüksek Lisans Tezi, İstanbul Üniv. Eğitim Bilimleri Enstitüsü, İstanbul 2017).

65 Tu 'ayme ve en-Nâka, el-Kitâbu'l-esâsî li-ta 'lîmi'l-lugati'l- 'Arabiyye li'n-nâtıkîne bi-lugâtin uhrâ, 87.

66 Temmam, el-Lugatu'l-'Arabiyye ma 'nâhê ve mebnâhê, 240-243.

67 Bkz. Mes'ûd Babayev, “Azerbaycan'da Okutulan Arapça Ders Kitaplarının Dört Temel Dil Becerisi Açısından Değerlendirilmesi”, (Yüksek Lisans Tezi, Gazi Üniv. Eğitim Bilimleri Enstitüsü, Ankara 2001), 29-39.

68 Howard ve Major, “Guidelines for Designing Effective English Language Teaching Materials”, 103.

69 Münire Gevrekçi, "Biçim ve Tasarım”, Konu Alanı Ders Kitabı İnceleme Kılavuzu, ed. Ayşegül Ataman, (Ankara: Nobel Yayın Dağıtım, 2001), 15; Tay, "Sosyal Bilgiler Ders Kitaplarında Öğrenme Stratejileri", 214.

70 Bkz. Babayev, "Azerbaycan'da Okutulan Arapça Ders Kitaplarının Dört Temel Dil Becerisi Açısından Değerlendirilmesi", 29-39; Tu'ayme ve en-Nâka, el-Kitâbu'l-esâsî li-ta 'lîmi'l-lugati'l- 'Arabiyye li'n-nâtıkîne bi-lugâtin uhrâ, 82. 
Fiziksel açıdan Arapça öğretiminde kullanılan materyallerin taşıması gereken belli bazı özellikler tespit edilmiştir. Bunlar aşağıdaki şekildedir; ${ }^{71}$

$\Rightarrow$ Seviye itibariyle başlangıç düzeyine yönelik tasarlanan materyallerin olabildiğine büyük hacimde, okunaklı ve anlaşılır olması.

$\Rightarrow$ Yazı çeşidi olarak nesih hattının kullanılması.

$\Rightarrow$ Satırlar arası boşlukların yeterli oranda olması.

$\Rightarrow$ Cümle ve satır uzunluğunun hedef kitlenin biyolojik yaş ve dil yeterliliğine uygun olması.

$\Rightarrow$ Sayfa hamurunun ışı̆̆ı yansıtmayacak bir yüzeye sahip olması

Sonuç itibariyle materyaller, öğrencilerin uzun süre kendileriyle vakit geçirdiği eserler olduğundan tasarlanmaları noktasında titiz çalışmaların yürütülmesini gerektirirler. Bu minvalde materyal tasarımlarında alanında uzman pek çok kişinin yardımına başvurarak, çok boyutlu hareket etmekte yarar vardir. ${ }^{72}$

\section{İ. Uygun Metnin Seçimi}

Uygunluk, hedef kitlenin dil öğrenme maksadıyla temel dil becerilerinin kullanımı ve materyallerin hazırlanması arasındaki uyumu ifade eden bir kavramdır. ${ }^{73}$ Richard Day, uygunluk kavramını "bünyesinde kimi ölçütleri bulunduran kozmos bileşenler bütünü" şeklinde tanımlar. Bu tür bileşenler "ilgi, okunabilirlik, konu, kültürel uygunluk ve görsel uygunluk" unsurlarından oluşur. ${ }^{74}$

\section{1. İlgi}

Kimi dilcilere göre bir okuma metninin okuyucuyu ilgilendirmesi ilkesi, onun metinden yararlanması veya metnin kendi dil seviyesine uygun olmasından daha önceliklidir. ${ }^{75}$ Materyallerin monotonluğu ve okuyucuya hitap edememe sorunu (özelde genç hedef kitleyi) genel manada tüm dil seviyesi ve yaş evresindeki kişileri ilgilendirmektedir. ${ }^{76}$

Okuma becerisi gibi yaygın eğitimde bireysel olarak sürdürülen faaliyetlerde hedef kitlenin hayati derecede önem vereceği olgular motivasyon

\footnotetext{
Tu'ayme ve en-Nâka, el-Kitâbu'l-esâsî li-ta 'limi'l-lugati'l- 'Arabiyye li'n-nâtıkine bi-lugâtin uhrâ, 53. Gevrekçi, "Biçim ve Tasarım", 14.

Tu'ayme ve en-Nâka, el-Kitâbu'l-esâsî li-ta 'limi'l-lugati'l- 'A rabiyye li'n-nâtıkîne bi-lugâtin uhrâ, 54. Day, "Selecting a Passage for the EFL Reading Class", 20.

Aktaran: Day, "Selecting a Passage for the EFL Reading Class", 20.

Taha-Thomure, "The Status of Arabic Language Teaching Today", 189.
} 
ve güdülenmedir. ${ }^{77}$ Esasen motivasyon kavramı, eylemlerin istikrar yakalamasıyla sebep sonuç ilişkisine sahiptir. ${ }^{78} \mathrm{Bu}$ konuya işaret eden Stephan Krashen, gelecekte yapılacak araştırmalarda dil öğrenen kitlelerin düş kırıklığ1 düzeyinin incelenerek ilgilerine hitap edecek materyallerin olduğundan daha iyi şekilde tasarlanmasını önerir. ${ }^{79}$ Arapça özelinde düşünüldüğünde ise hedef kitlenin Arapçadan beklenti ve ihtiyaçları nazarı itibara alınarak metin içeriklerinin oluşturulması gerekecektir.

\section{Okunabilirlik}

Okunabilirlik kavramiyla okuma materyallerinin arka plan ve kelime bilgisinin hedef kitleye uygun dizaynı kast olunur. Özel manada okunabilirlik, sözdizimsel uyumu, düşüncelerin mantıki sıralanışı, metnin uzunluğu ve kelimelerin söylemsel kurgusu gibi meseleleri içerir. ${ }^{80}$ Diğer bazı dilcilere göre ise okunabilirlik, kelime ve bağlaçların çeşitliliği, cümle ve paragrafların uzunluk ve dizaynı, resim-şekil benzeri açıklayıcı görseller, fikirsel çeşitlilik, konuların ele alınma şekli, düşüncelerin aktarımı ve kullanılan anlatım tarzından oluşur. ${ }^{81}$ Okunabilirliğin kısımlarından bazılarını ele almakta fayda olduğu kanaatindeyiz.

\section{(a). Kelime Bilgisi}

Okunabilirliğe etki eden temel aktörlerdendir. Pozitif ilgileşimle metinde bilinmeyen unsurların çokluğu okuma becerisinin zorluk derecesinde artışa neden olur. Okuyuculara yönelik materyal tasarımı ve seçiminde sözcük haznesinin zorluk seviyesi ve bilinmeyen kelime oranının nasıl belirleneceği tartışma konusudur. Bu bağlamda materyaldeki kelime miktarı, çeşitliliği ve cümlelerin uzunluğu, hedef kitlenin yaş aralığı ve dil seviyesine uyumlu olmalıdır. ${ }^{82}$

\footnotetext{
77 Day, "Selecting a Passage for the EFL Reading Class", 20.
}

78 Richard C. Anderson, Elfrieda H. Hiebert, Judith A. Scott, Ian A.G. Wilkinson, Becoming a Nation of Readers: The Report of the Commission on Reading, (Washington: National Academy of Education, 1985), 14.

79 Dolly J. Young, "Language Anxiety from the Foreign Language Specialist's Perspective: Interviews with Krashen, Omaggio Hadley, Terrell and Rardin", Paper presented at the Annual Meeting of the Central States Conference on the Teaching of Foreign Languages, (Indianapolis: 1991), 28.

80 Day, "Selecting a Passage for the EFL Reading Class", 20.

81 Tu ayme ve en-Nâka, el-Kitâbu'l-esâsî li-ta 'lîmi'l-lugati'l- 'Arabiyye li'n-nâtıkîne bi-lugâtin uhrâ, 53-54.

82 Tu'ayme ve en-Nâka, el-Kitâbu'l-esâsî li-ta 'lîmi'l-lugati'l-'Arabiyye li'n-nâtıkîne bi-lugâtin uhrâ, 29. 


\section{(b). Arkalan (Arka Plan) Bilgisi}

Okuma becerisinde anlama yetisinin ön koşullarından birisi içerik hakkında bilgi sahibi olmaktır. ${ }^{83}$ Öncelikle hedef dilin kültürüyle ilgili yeterli seviyede bilgiye ulaşılmalıdır. Özellikle dilin öğrenilme amacı ve ihtiyacı noktası hedef kitlenin önünü aydınlatacaktır. ${ }^{84}$ Arapça gibi tarihi oldukça köklü bir dilin öğrenilmesi söz konusu olduğunda arka plan bilgisine yapılan vurgu çok daha güçlü olacaktır. Kutsal kitap ve İslam kültürel mirasının 14 asırlık dil mazisine sahip Arapçanın dünü ve bugünü arasında sosyolojik anlamda büyük evrilmeler yaşanmıştır. Asırlar öncesine ait eserlerin okunup anlaşılması da dönemin sosyolojik gerçekliğinden haberdar olmayı zorunlu kilmaktadır.

\section{(c). Sözdizimsel Uygunluk}

Bu konuyla metnin sözdizimsel yapılarının okunabilirliği meselesi kastedilir. Okuyucuların zayıf ve güçlü yönlerini tespit etmede çeşitli faaliyetler yürütülür. Bu bağlamda metnin ilk okunmasında tarama yoluyla anlaşılması güç sözdizimsel yapılar işaretlenerek tespit edilebilir. ${ }^{85}$ En yaygın işaretleme şekli ise altını çizmedir. Anlamı bilinmeyen veya ilk okumada anlaşılamayan yapılar dışında anlatılan konuyu bölümlere ayırmak amacıyla da bu işleme başvurulabilir. Bu sayede kısa süreli belleğin yükü hafifleyecektir. ${ }^{86}$ Altını çizme işlemleri için kullanılan teknik ve donanımda aranan temel özellik ise dikkat celp edici olmadır. ${ }^{87}$

\section{(d). Organizasyon}

Metnin retorik bakımdan organize yapıda tasarlanmasını ifade eder. Retorikten uzak metinler anlaşılmada problemlere neden olur.

\section{(e). Okuma Metninin Uzunluğu}

Metin ve cümle uzunlukları, materyal tasarımında hatanın sıkça rastlandığı alanlardandır. ${ }^{88}$ Temel bir esas gereği, cümle uzunlukları -mümkün olduğunca- çok uzun veya çok kısa olmamalıdır. Dengenin sağlanamadı̆̆

\footnotetext{
83 Zehra Çakıcı, "Almanya ve Türkiye'deki Anaokullarında Verilen Anadili Eğitiminde Kullanılan Oyunların Çocukların Temel Dil Becerilerine Etkisi”, (Yüksek Lisans Tezi, Marmara Üniv. Eğitim Bilimleri Enstitüsü, İstanbul 2016), 40.

84 Dan Dougles, Assessing Language for Specific Purposes, (b.y.: Cambridge Universty Press, 2000), 20.

85 Day, "Selecting a Passage for the EFL Reading Class", 20.

Halit Karatay, Okuma Eğitimi: Kuram ve Uygulama, 2. bs. (Ankara: Pegem Akademi, 2014), 62.

Sönmez, Ögrretim İlke ve Yöntemleri, 66-67.

Day, "Selecting a Passage for the EFL Reading Class", 20.
} 
durumlarda okuyucuların okuma zevk ve alışkanlıkları olumsuz yönde etkilenecektir. ${ }^{89}$ Anadili (kısa cümle kurgusu özelliğine sahip) Türkçe olan hedef kitle, Arapçanın uzun cümle yapısına alışmada ciddi sorunlar yaşayabilir. Bu bakımdan Arapça materyallerde kullanılan metinlerdeki cümle uzunlukları, -başlangıç seviyesinden itibaren- Türk dil mantığına çok ağır gelmeyecek tarzda tedrici olarak seçilmeli veya tasarlanmalıdır.

\section{Konu}

Metinlerde işlenen konular, hedef dil kültürünü yansıtan emareler taşır. Arap ülkelerindeki okuma metinleri genel ifadeyle milli, siyasi, dini ve beşeri temalara yoğunlaşmıştır. Ancak bu tür metinlerde içerik itibariyle gerçeklikten uzak, abartılı ve süslü anlatımlara rastlanabilmektedir. ${ }^{00}$ Hedef dildeki metinlerin -belli oranda- Arap kültürüne dair ögeler taşıması elbette doğaldır. Ancak içerisinde yaşanılan sosyolojik gerçeklikten ötürü konu ekseninin Türkiye şartları ve ihtiyaçlarını kuşatması gerekmektedir.

\section{Siyasî ve Kültürel Uygunluk}

Hedef dildeki metinlerde ele alınan konular, dil öğrenen kişilerin aidiyetleri bulunan ülke ve milletlerin siyasi ve kültürel dokusuna uyum sağlamalı, onlarla çatışmamalıdır.

\section{Materyalin Görünümü}

Bu konu başlığı, materyal tasarımıyla ilişkili bazı konuları içermektedir. Bunlardan bazıları aşağıdaki şekildedir:

\section{(a). Düzen}

Günümüzde bilgiye ulaşma imkânı sınır tanımayan derecede artış gösterse de bu bilgilerin belli bir düzen ve tertip çerçevesine oturtulma gerekliliği mevcuttur. Böylece gerek zamandan tasarrufta bulunulacak gerekse bilginin öğrenilme kalitesi yükselecektir. ${ }^{91} \mathrm{Bu}$ bağlamda materyallerde sayfa ebatı, sayfa sayısı ve cilt adedi hedef kitlenin dil yeterliliğiyle uyumlu olma-

89 Firdevs Güneş, “Türkçe Öğretiminde Günümüz Gelişmeleri ve Yapılandırıcı Yaklaşım”, Mustafa Kemal Üniversitesi Sosyal Bilimler Enstitüsü Dergisi, 6/11 (2009): 16.

90 Derya Adalar, “Anadili Olarak Arapça ve Türkçenin Öğretimde Kullanılan Metinlerin Karşılaştırılması: Bir Eşdizimsel Örüntüleme Çözümlemesi Örneği”, (Yüksek Lisans Tezi, Ankara Üniv. Sosyal Bilimler Enstitüsü, Ankara 2004), 133-134.

91 Stephen Krashen, "The Case for Narrow Reading", Language Magazine, 3/5 (2004): 17-19; Howard ve Major, "Guidelines for Designing Effective English Language Teaching Materials", 103-107. 
lıdır. ${ }^{92}$ Genel anlamda bir kitabın sahip olabileceği boyut, küçük (12*21), orta $\left(18^{\star} 24\right)$ ve büyük $\left(21^{*} 28\right)$ şeklinde üç çeşide ayrılır. Başlangıç seviyesindeki materyallerin pedagojik açıdan büyük ebatta olması gerekecektir. Ancak tüm dil seviyelerine hitap edebilen materyal boyutu ise orta ebattır. ${ }^{93}$

\section{(b). Yazıların Karakteristiği (Yazı Boyut ve Stili)}

Bu konu özellikle başlangıç seviyesindeki hedef kitle açısından önem arz eder. Materyallerin fiziki dizaynı, içerisinde yazı karakteristiğini de barındırır. Metnin karakter yoğunluğu ve yazılı sembollerin boyutu güdülenme ile ilişki içerisindedir. ${ }^{94}$

Metnin araçsal faaliyeti (okuma) vasıtasıyla amaçsal gaye olan anlama ulaşılmakta ve kod çözümlemesi gerçekleşmektedir. Sembollerden oluşan kodlar ise dil seviyelerine göre farklılaşır. Başlangıç seviyesine hitaben metnin yazı karakteri normal boyutların üstünde seçilmelidir. Bazı dilciler başlangıç seviyesindeki okumalarda zihinsel yönden rahatlamanın 14 punto büyüklüğünde yazı karakteri ve 1.5 oranında satır aralığıyla gerçekleşeceği düşüncesindedir. ${ }^{95}$ Ancak ilerleyen dil seviyesiyle birlikte bu denli bir yazı büyüklüğü olumsuz etkiler doğuracaktır. Zira yazı karakterinin büyümesiyle gözün görme alanı daralmakta ve okuma hızı gerilemektedir. ${ }^{96}$ Sonuç itibariyle okuma seviyesi ileri düzeyde olan kimselere yönelik tasarlanan materyallerde yazı karakteristiği olabildiğince küçük; başlangıç ve orta düzeylerde ise daha büyük olmalıdır.

\section{K. Dar Okuma}

Dil öğrenmedeki esas gaye, dilin bir araç görevi üstlenerek hedef kitlenin sosyal ihtiyaçlarını kendisiyle giderebilmesidir. Bu kapsamda materyallerin ele aldıkları konu, içerik bakımından savruk olmayan, dil öğrenme ihtiyacına hitap edebilen tarzda oluşturulmalıdır. Okuyucuların ilgi alanına uyumlu yazılar, gerek arka plan bilgisine sahip olunması gerekse dil öğrenmede güdüleyici olmaları bakımından gayet fayda sağlayıcıdır. Materyal içeriğinin kapsam itibariyle dar okumaya uygunluğu yanında okuyucuların

\footnotetext{
92 Tu'ayme ve en-Nâka, el-Kitâbu'l-esâsî li-ta 'lîmi'l-lugati'l- 'Arabiyye li'n-nâtıkine bi-lugâtin uhrâ, 83.

93 Tu 'ayme ve en-Nâka, el-Kitâbu'l-esâsî li-ta 'lîmi'l-lugati'l- 'A rabiyye li'n-nâtıkine bi-lugâtin uhrâ, 84.

94 Taha-Thomure, "The Status of Arabic Language Teaching Today", 189; Day, Selecting a Passage for the EFL Reading Class", 20.

95 Duman ve Çifci Tekinarslan, "Hikâye Haritası Yönteminin Hafif Düzeyde Zihinsel Yetersizliği Olan Öğrencilerin Okuduğunu Anlama Becerileri Üzerindeki Etkisi", 38.

96 Day, Selecting a Passage for the EFL Reading Class", 20; Zeki Kaya, Öğretim Teknolojileri ve Materyal Geliştirme, 3. bs. (Ankara: Pegem Yayıncılık, 2006), 89.
} 
ihtiyaçlarına karşılık verebilecek sosyal konu çeşitliliğine de sahip olması gerekir. Zira çeşitliliğin sağlanamadığı dar okumalarda güdülenmenin etkisi menfi yönlü seyredecektir. ${ }^{97}$

\section{Sonuç}

Yaygın öğrenmenin bilgiye ulaşma noktasında sağladığı avantajlar, geçmişe kıyasla oldukça gelişmiş vaziyettedir. Materyaller, yaygın eğitim faaliyetlerinin kendisiyle yürütüldüğü temel kaynaklardır. Özellikle okuma dil becerisine hitap eden bu merciler yabancı dil öğrenme sürecinin vazgeçilmezleridir. Geçmiş yıllardaki Arapça öğretiminde materyallerin nicelik açısından yaşadığı problemler günümüzde yerini niteliksel problemlere bırakmıştır. Basın-yayın organlarının ciddi manada yaygınlaştığı bu günlerde materyal tasarlamak oldukça olağan ve basit bir hal almıştır. Ancak materyal tasarımı meselesi gelişigüzel reaksiyonlarla hareket edilecek bir alan asla değildir. Zira böylesi bir başıboşluk ortamında Arapça öğrenmek isteyen kişiler, pedagojik açıdan son derece yanlış şekilde tasarlanmış materyallerle muhatap olabilmekte ve Arapçanın öğrenilmesi mümkün olmayan bir dil olduğu intibaına kapılabilmektedirler. Güdülenmeleri böylesine menfice uyarılmış kitlelerin Arapçaya bakışı iyimser olmayacaktır. Bu bağlamda, materyal tasarlamada ortak paydayı oluşturan temel ilkelerin tespitinin gerekli ve mümkün olduğu gayet ortadadır. Ayrıca Arap dili, öğrenilmesi zor olmakla beraber pedagojik yapıda tasarlanan materyallerin kalitesi Arapçanın öğrenilmesine hatırı sayılır derecede katkı sağlayacaktır.

\section{Kaynakça}

Adalar, Derya. "Anadili Olarak Arapça ve Türkçenin Öğretimde Kullanılan Metinlerin Karşılaştırılması: Bir Eşdizimsel Örüntüleme Çözümlemesi Örneği". Yüksek Lisans Tezi, Ankara Üniv. Sosyal Bilimler Enstitüsü, Ankara 2004.

Allen, Virginia French. Techniques in Teaching Vocabulary. Oxford: Oxford University Press, 1983.

97 Şakir Demirbaş, “Türkiye'de İmam-Hatip Ortaokullarında Okutulmakta Olan Arapça Ders Kitabı Serisi İle İlgili Öğretmen ve Öğrenci Görüşleri”, (Yüksek Lisans Tezi, Gazi Üniv. Eğitim Bilimleri Enstitüsü, Ankara 2016), 79; Serena Yeo. "The ESP Coursebook: Effects on an in-Service Training Programme in Slovakia", Teacher Education for Languages for Specific Purposes, ed. Ron Howard and Gillian Brown, (y.y.: Multilingual Matters, 1997), 149. 
Anderson, Richard C. ve Hiebert, Elfrieda H. ve Scott, Judith A. ve Wilkinson Ian A.G. Becoming a Nation of Readers: The Report of the Commission on Reading. Washington: National Academy of Education, 1985.

Aydın, Mehmet Zeki. “Arapçayı Nasıl Öğretelim?”. Din Öğretiminde Yeni Yaklaşımlar, Der. Mualla Selçuk, 3-38. İstanbul: Mili Eğitim Bakanlığı, 2000.

Babayev, Mesud. “Azerbaycan'da Okutulan Arapça Ders Kitaplarının Dört Temel Dil Becerisi Açısından Değerlendirilmesi". Yüksek Lisans Tezi, Gazi Üniv. Eğitim Bilimleri Enstitüsü, Ankara 2001.

Barın, Erol. "Yabancılara Türkçenin Öğretilmesinde Bir Metod Denemesi”. Yüksek Lisans Tezi, Gazi Üniversitesi Sosyal Bilimler Enstitüsü, Ankara 1992.

Başoğlu, Emrah Baki. “Cep Telefonu ve Sözcük Kartı Kullanan Öğrencilerin İngilizce Sözcük Öğrenme Düzeylerinin Karşılaştırması”. Yüksek Lisans Tezi, Zonguldak Karaelmas Üniv. Sosyal Bilimler Enstitüsü, Zonguldak 2010.

Bloom, Benjamin S. Taxonomy of Educational Objectives: The Classification of Educational Goals: Handbook 1 Cognitive Domain. USA: Longmans, 1956.

Bloor, Mariel ve Bloor, Thomas. Language for Specific Purposes: Practiice and Theory. CLCS Occasional Paper No. 19. Trinity Coll. Dublin: Centre for Language and Communication Studies, 1986.

Bostanc1, Ahmet. "Ürdün Üniversitelerinde Yabancılara Arapça Öğretimi”. Sakarya Üniversitesi İlahiyat Fakültesi Dergisi, 5/8 (2003): 53-98.

Carver, David. “Some Propositions About ESP”. The ESP Journal, $2 / 2$ (1983): 131-137.

Ceyhan, Erdal ve Yiğit, Birol. Konu Alanı Ders Kitabı İncelemesi. Ankara: Anı Yayınc1lik, 2003.

Cook, Vivian. Second Language Learning and Language Teaching. 4. bs., London: Hoder Education an Hachette UK Company, 2008.

Coşkun, Eyyup. “İlköğretim Öğrencilerinin Öyküleyici Anlatımlarında Bağdaşıklık, Tutarlılık ve Metin Elementleri". Doktora Tezi, Gazi Üniv. Eğitim Bilimleri Enstitüsü, Ankara 2005.

Çakmak, Melek. "Yabancı Dil Öğretimi". Konu Alanı Ders Kitabı İnceleme Kılavuzu, der. Ayşegül Ataman, Ankara: Nobel Yayın Dağıtım, 2001.

Çırpıcı Çiğdemi, Elif. "Yabancı Bir Dil Olarak Arapça Nasıl Öğretilir”. Haziran 2015 Arapça ve Mesleki Arapça Mesleki Çalı̧̧ma Tebliğleri, 13-29.

Day, Richard R. "Selecting a Passage for the EFL Reading Class". ELT FORUM, 32/1 (1994): 20. 
Demirbaş, Şakir. “Türkiye' de İmam-Hatip Ortaokullarında Okutulmakta Olan Arapça Ders Kitabı Serisi İle İlgili Öğretmen ve Öğrenci Görüşleri”. Yüksek Lisans Tezi, Gazi Üniv. Eğitim Bilimleri Enstitüsü, Ankara 2016.

Demirel, Özcan. Yabancı Dil Öğretimi; İlkeler, Yöntemler, Teknikler. 2. bs., Ankara: Usem Yayınları, 1990.

Dilidüzgün, Şükran. “Türkçe Öğretiminde Metindilbilimsel Bağlamda Uygulamalı Bir Yaklaşım". Doktora Tezi, İstanbul Üniv. Sosyal Bilimler Enstitüsü, İstanbul 2008.

Dohmen, Gunther. "Yetişkinlerin Eğitimi İçin Yeni Bulgular". çev. İlhan Tomanbay, Eğitim ve Bilim, 2/12: 22-26.

Dougles, D. Assessing Language for Specific Purposes. b.y.: Cambridge Universty Press, 2000.

Dörnyei, Zoltan. Motivational Strategies in the Language Classroom: Cambridge Language Teaching Library. Cambridge: Cambridge University Press, 2001.

Duman, Nesibe ve Çifci Tekinarslan, İlknur. "Hikâye Haritası Yönteminin Hafif Düzeyde Zihinsel Yetersizliği Olan Öğrencilerin Okuduğunu Anlama Becerileri Üzerindeki Etkisi". Özel Eğitim Dergisi, 8/1 (2007): 33-55.

Er, Abdullah. "Yabancı Dil Öğretiminde 'Okuma'”. Kazım Karabekir Eğitim Fakültesi Dergisi, 12/ (2005): 208-218.

Erkman, Akerson Fatma. Türkçe Örneklerle Dile Genel Bir Bakış. 2. bs., İstanbul: Multilingual, 2008.

Ertürk, Nazan. “Türkiye'de Arapça Öğretimi Açısından 'İmam Hatip Liseleri Yeni Programa Uygun Arapça' Adlı Ders Kitabı Serisinin Değerlendirilmesi”. Yüksek Lisans Tezi, Gazi Üniv. Eğitim Bilimleri Enstitüsü, Ankara 2004.

Flowerdew, John ve Peacock, Matthew. 1. bs., Research Perspectives on English for Academic Purposes. Cambridge: Cambridge Universty Press, 2001.

Gevrekçi, Münire. “Biçim ve Tasarım”, Konu Alanı Ders Kitabı İnceleme Kılavuzu. ed. Ayşegül Ataman, Ankara: Nobel Yayın Dağıtım, 2001.

Güneş, Firdevs. “Türkçe Öğretiminde Günümüz Gelişmeleri ve Yapılandırıcı Yaklaşım”. Mustafa Kemal Üniversitesi Sosyal Bilimler Enstitüsü Dergisi, 6/11 (2009): 1-21.

Helvacı, Onur. “Okuma Ediniminde Bağlam İpuçlarının Sözcük Edinimine Etkisi”. Yüksek Lisans Tezi, Yıldız Teknik Üniv. Sosyal Bilimler Enstitüsü, İstanbul 2004. 
Howard, Ron ve Brown, Gillian. Teacher Education for Languages for Specific Purposes. Clevedon: Multilingual Matters, 1997.

Hulstijn, Jan H. "Intentional and İncidental Second Language Vocabulary learning: A Reappraisal of Elaboration, Rehearsal and Automaticity". Congnition and Second Language Instruction, ed. Peter Robinson, 258-286. Cambridge: Cambridge University Press, 2001.

Hulme-Kukulska, Agnes ve Shield, Lesley. “An Overview of Mobile Assisted Language Learning: From Content Delivery to Supported Collaboration and İnteraction". European Association for Computer Assisted Language Learning, 20/3 (2008): 271-289.

Hulme-Kukulska, Agnes. "Will mobile learning change language learning?". European Association for Computer Assisted Language Learning, 21/2 (2009): 157165.

Howard, Jocelyn ve Major, Jae. “Guidelines for Designing Effective English Language Teaching Materials". The Tesolanz Journal,12/1 (trsz.): 101-109.

Javad, Gholami ve Azarmi, Ghader. “An İntroduction to Mobile Assisted Language Learning". International Journal of Management in Education, 2/ 8 (2012): 1-9.

Kalkan, Ekrem. “Avrupa Dilleri Ortak Çerçeve Programı Kapsamında Türkiye'de Yabancı Dil Öğretmeni Yetiştirme Politikaları". Yüksek Lisans Tezi, İstanbul Üniv. Eğitim Bilimleri Enstitüsü, İstanbul 2017.

Kaman, Şafak. “Akıcı okuma Stratejilerini Kullanmanın İlköğretim Üçüncü Sınıf Öğrencilerinde Okuma Becerisini Geliştirmeye Etkisi”. Yüksek Lisans Tezi, Ahi Evran Üniv. Sosyal Bilimler Enstitüsü, Kırşehir 2012.

Karatay, Halit. Okuma Eğitimi: Kuram ve Uygulama. 2. bs., Ankara: Pegem Akademi, 2014.

Kaya, Zeki. Öğretim Teknolojileri ve Materyal Geliştirme. 3. bs., Ankara: Pegem Yayınc1lik, 2006.

Kekevi, İbrahim. “Erenlerin Bağından Adlı Şiir Metni Üzerine Metindilbilimsel İnceleme". Yüksek Lisans Tezi, Pamukkale Üniv. Sosyal Bilimler Enstitüsü, Denizli 2015.

Kılıç,Abdurrahman; Seven, Serdal. Konu Alanı Ders Kitabı Incelemesi. 7. bs., Ankara: Pegem A Yayıncilık, 2008.

Koç, Sabri ve Müftüoğlu, Güneş. “Dinleme ve Okuma Öğretimi”. Türkçe Öğretimi, der. Seyhun Topbaş, 53-70. Eskişehir: Anadolu Üniversitesi Yayınları: Aç1köğretim Fakültesi Yayınları, 1998. 
Korkmaz, Hünkar. “Çoklu Zeka Kuramı Tabanlı Etkin Öğrenme Yaklaşımının Ö ğrenci Başarısına ve Tutumuna Etkisi”. Eğitim ve Bilim, 26/119 (2001): 71-78.

Laufer, Batia. "What percentage of text-lexis is essential for comprehension?", Special Language: From Humans Thinking to Thinking Machines. ed. Christer Lauren, Marianne Nordman, 316-323. USA: Multilingual Matters, 1989.

Master, Peter. "ESP Teacher Education in the USA", Teacher Education for Languages for Specific Purposes. ed. Ron Howard, Gillian Brown, 22-40. Clevedon: Multilingual Matters, 1997.

Naismith, Laura ve Lonsdle, Peter ve Vavoula, Giasemi ve Sharples, Mike. Literature Review in Mobile Technologies and Learning. Birmingham: Futurelab Series, 2004.

en-Neccar, Muhammed Țayyibi. el-Lugatü'l- 'Arabiyyetü'l-mu 'âsıra. b.y: y.y., trsz.

Ömer, Temmam Hassan. el-Lugatu'l- 'Arabiyye ma nâhê ve mebnâhê, 5. b.s., b.y.: 'Âlemu'l-Kutub, 2006.

Prensky, Marc. “What Can You Learn from a Cell Phone? Almost Anything!”, Harnessing the Potential of ICT for Education: A Multistakeholder Approach, United Nations ICT Task Force. ed. Bonnie Bracey, Terry Culver, 271-279. New York: y.y., 2005.

Pwint, Hnin. "Learning on the Move: The Use of Mobile Technologies for Language Skill Development". Executive Journal, 34/1 (2014): 98-107.

Saragi. T. ve Nation, I. S. P. ve Meister, G. F., “Vocabulary Learning and Reading”. System, 6/2 (1978): 72-78.

Saran, Murat ve Çağıltay, Kürşat ve Seferoğlu, Gölge. “Use of Mobile Phones in Language Learning: Developing Effective Instructional Materials". Fifth IEEE International Conference on Wireless, Mobile and Ubiquitous Technologies in Education - WMUTE, 23-26 Mart 2008 Beijing, (Beijing: 2008), 39-43.

Sarrab, Mohamed ve Elgamel, Laila ve Aldabbas, Hamza. “Mobile Learning (MLearning) And Educational Environments". International Journal of Distributed and Parallel Systems (IJDPS), 3/4 (2012): 31-38.

Senemoğlu, Nuray. Gelişim Öğrenme ve Öğretim: Kuramdan Uygulamaya. 7. bs., Ankara: Gazi Kitabevi, 2005.

Seyfulislam, Muhammed. "Ta lîmu'l-lugati'l-Arabiyye beyne'r-ru'ye'l-fenniyye ve'nnazariyyâti'l- 'ilmiyye". Âfâku's-Sekâfe ve't-Turâs, (2013): 6-33.

Sheldon, Leslie E. ELT Textbooks and Materials: Problems in Evaluation and Development. y.y.: Modern English Publications, 1987. 
Sönmez, Veysel. Öğretim İlke ve Yöntemleri. 2. bs., Ankara: Anı Yayınları, 2008.

Stockwell, Glenn. "Vocabulary on the Move: İnvestigating an İntelligent Mobile Phone-Based Vocabulary Tutor". Computer Assisted Language Learning, 20/4 (2007): 365-383.

Şahin, Ayten. “Avrupa Dil Gelişim Dosyası Bağlamında Yabancı Dil Olarak Türkçe Öğretiminde Okuma Becerisini Geliştirmeye Yönelik Malzeme Oluşturma". Yüksek Lisans Tezi, Dokuz Eylül Üniv. Eğitim Bilimleri Fakültesi, İzmir 2010.

Taha-Thomure, Hanada, "The Status of Arabic Language Teaching Today". Education, Business and Society: Contemporary Middle Eastern Issues, 1/3 (2008): 186-192.

Tanın, Reyhan. “Yabancı Dil Olarak Türkçe Öğretiminde Sözcük Bilgisi ve Öğretimi". Yüksek Lisans Tezi, İstanbul Üniv. Sosyal Bilimler Enstitüsü, İstanbul 2004.

Tay, Bayram. "Sosyal Bilgiler Ders Kitaplarında Öğrenme Stratejileri”. Gazi Üniversitesi Kırşehir Eğitim Fakültesi Dergisi, 6/1 (2005): 209-225.

Tomlinson, Brian. Materials Development in Language Teaching. 2. bs., Cambridge: Cambridge University Press, 2011.

Tarakçıŏlu, Aslı Özlem ve Tunçarslan, Hatice Kübra. “The Effect of Short Stories on Teaching Vocabulary to Very Young learners (Aged 3-4-year): A Suggested Common Syllabus". Journal of Language and Linguistic Studies, 10/2 (2014): 67-84.

Tu'ayme, Rüşdi Ahmed ve en-Nâka, Mahmud Kamil. el-Kitâbu'l-esâsî li-ta 'lîmi'llugati'l- 'Arabiyye li'n-nâtıkîne bi-lugâtin uhrâ. 1. bs., Mekke: y.y., 1983.

Uçkun, Berrin ve Onat, Zişan. "Yabancı Dil Kitaplarında Özgün Metin ve Özgün Görev Kullanımının Önemi: Bir Kitap İncelemesi”. Gaziantep Üniv. Sosyal Bilimler Dergisi, $7 / 1$ (2008): 149-164.

Yaran, Rahmi. Arapçada İ'rab. 4. bs., İstanbul: Rağbet Yayınları, 2016.

Yeo, Serena. "The ESP Coursebook: Effects on an in-Service Training Programme in Slovakia". Teacher Education for Languages for Specific Purposes, ed. Ron Howard and Gillian Brown, y.y.: Multilingual Matters, 1997.

Waring, Rob ve Takaki, Misako. “At What Rate Do Learners Learn and Retain New Vocabulary From Reading a Graded Reader?". Reading in a Foreign Language, 15/2 (2003): 130-163. 
Waring, Rob ve Nation, Paul. "Second Language Reading and Incidental Vocabulary Learning". Museum Tusculanum Press: The University of Copenhagen, 4/1 (2004): 11-23.

West, Michael. A General Service List of English Words. London: Longman, 1953.

Nagy, William E., ve A. Herman, Patricia ve Anderson, Richard C. "Learning Words from Context". Reading Research Quarterly, 20/2 (1985): 223-253.

Yıldız, Nur. “Arapça Sözcük Öğretiminde Yapılan Uygulamalar: İlahiyat Fakültesi Örneği”. Yüksek Lisans Tezi, Marmara Üniv. Sosyal Bilimler Enstitüsü, İstanbul 2009.

Young, Dolly J. “Language Anxiety from the Foreign Language Specialist's Perspective: Interviews with Krashen, Omaggio Hadley, Terrell and Rardin". Paper presented at the Annual Meeting of the Central States Conference on the Teaching of Foreign Languages, (Indianapolis: 1991), 5-28. 


\title{
Doi: 10.34247/artukluakademi.551118
}

\section{Ramazan Kılıç}

\author{
Evaluating Material Design in Arabic Reading Skills from Pedagogical \\ Perspective
}

Citation/@: Kılıç, Ramazan, Evaluating Material Design in Arabic Reading Skills from Pedagogical Perspective, Artuklu Akademi 2019/6 (1),35-65.

\section{Extended Abstract}

This research is about evaluating the design of the reading materials prepared for Arabic teaching as a second language. First of all, it is important to note that any draft of joint regulations regarding the basic principles and rules for teaching materials are unfortunately not available. Nowadays, due to the fact that printing is very easy, many reading materials for foreign language teaching are presented to the market. Although the problem of material shortage was eliminated in this way, with this progress other problems arose. This article focuses on the problem of the design of teaching material designs. Teaching materials in Arabic are widely accessible, but they are not at the expected the quality in the design point. For this reason, it should be determined which criteria should be regarded in materials designed for Arabic teaching (and other second/foreign languages). In this research, the criteria in designing materials for foreign language teaching, in particular Arabic, are discussed, as follows:

1. Utilization from original materials: Texts for reading skills are usually prepared in two different ways. One of the most common methods is either altering the chosen text or replacing by an existing text. Whichever method is used to choose a reading text in Arabic teaching, the main point to remark is the authenticity of the text. For this reason, the person who wrote the text should know the logic of the Arabic language very well. If not, the text in Arabic will represent the logic of Turkish (or any other language). The same applies to interventions in an original text. To solve this problem, it can be suggested that the text design should be undertaken by the people who learned Arabic as a second language (who has already experienced the challenges of learning a foreign language) and by the native speakers.

2. To Benefit from the visual aids: Another important point in preparing a reading material is the content provided as an input to the target group. The visual means used in the presentation of the information as well as the information itself should be considered while putting together the reading material. In other words, it is necessary to use visual aids. The subject of the text, which is arranged in accordance with the level of the target group, makes the language learning process more enjoyable.

3. Vocabulary list and text translation: Words play the most important role in understanding the text. It is not possible for the target group to carry out the reading in a healthy way when the ratio of known words in the text is low. For a second language learner, it is usual to encounter unknown words regardless of the level of the target group. For this reason, it would be a useful option to add word lists to the texts for the target. In addition to the word list, text transla- 
tions need to be placed in various locations of the material according to the language level of the target group.

4. Arabic common word core: Regardless of the purpose of learning the target language, all languages focus on certain common words used in specific fields. For instance, in Arabic, which is also used in the field of social sciences and science, the technical terms and concepts used by them differentiate. At the same time, there is considerable number of shared words by those fields. This partnership is expressed by the common core concept. This situation, which constitutes the basic structure of the language, must be constantly observed in the reading texts.

5. A suitable Text design for each language level: The extent to which a text is suitable for the targeted language level can be evaluated in two ways. These are vocabulary and grammar. Linguists have investigated the number of words that need to be known in order to understand the average text in a healthy way. According to this, the knowledge of approximately 5000 words is accepted as sufficient to understand $95 \%$ of the text. However, if the text is on a specific subject and contains more technical terms, the number of unknown words will increase. According to this result, it is necessary to have 5000 or more words in Arabic reading materials.

The issue to be addressed in terms of grammar for Arabic is the insertion of vowel-point and the case system (al-i'rāb). In Arabic, only the use of consonants is essential. In addition, the last letters of the words determine the role of the word in the syntax. Despite the fact that they have a highly systematic vocabulary derivation structure, the fact that Arabic language does not contain vowels is a compelling condition that even compels the Arabic native speakers. The characters called the insertion of vowel-points designed lately to meet the vowels. However, it is essential to know that the vowels are not specified in the Arabic. This feature should be regarded, while designing Arabic reading materials.

It is seen that the insertion of vowel-points in text books have been applied in three ways. Either, the entire text is subjected to insertion of vowel-points, or no insertion of vowel-points is performed. Or, sometimes, as an exception, the insertion of vowel-points can be applied in some part of the text. According to our opinion, taking account of text levels the process should be as follows: For the beginner level, the insertion of vowel-points should be applied to the whole text. In intermediate texts, the insertion of vowel-points should be used in certain places and in upper intermediate level, (as far as possible) progressive insertion of vowel-points should be avoided. For the advanced reading texts, insertion of vowel-points should not be used except in exceptional cases. Through gradual insertion of vowel-points, the target group will become accustomed to read a text without a vowel style.

6. Physical appearance and ease of using materials: The material content is important as well as the way in which this content is exhibited. It is necessary to pay more attention to visual exhibition which is often neglected. 
7. Choosing the most appropriate text: The process of selecting appropriate reading material covers certain topics. The texts should be selected according to the target group. Having background knowledge about the topic of the text will help the reader to understand the text easier. It is important to note that the length of the texts should be arranged to the language level of the target group.

8. The Problem of narrow reading: Whatever the purpose of learning a language is, it is necessary to read texts on diverse subjects. In this way, the target group will be able to dominate the different usage areas of the language. On the other hand, this does not mean that the readings appropriate to the purpose of learning the language should be neglected. By following this way, it will be easier to focus on the language learning process. 